\title{
THE HISTORICAL CONTEXT OF AMERICAN INDIAN LEGAL PROBLEMS
}

\author{
Wilcomb E. WASHBURN*
}

Few people realize that American Indians comprise the only minority group which possesses a special legal status within the United States. Although they are citizens like everybody else, they are also, by virtue of their tribal affiliations, possessed of special rights. This special status has puzzled and sometimes irritated white Americans. Indeed, so august a body as the Supreme Court of the State of Washington, in Makah Indian Tribe $\%$. Clallam County observed: ${ }^{1}$

Although the natural dignity of the American Indian as a person and a citizen, his valor as a warrior, and his contributions to this country, military and civil, cannot and ought not be denied, one wonders, as he reads the case law on Indian matters, whether the law has not conferred upon tribal Indians and their descendants what amounts to titles of nobility, with all that entails, in contravention of Article 1, \& 9, of the United States Constitution prohibiting such titles. But this is a question beyond our jurisdiction.

While strong support for this special legal status of the American Indian is not immutable, Indian tribes presently enjoy what can be described as "internal sovereignty" or "local autonomy" in their respective jurisdictions. This paper will attempt to show how this status derives directly from the peculiar historical experiences of Indians and whites in the New World.

The experience of Indian-white relations in the United States has always differed from that in other parts of this hemisphere. In Latin America, for example, the relationship between Europeans and natives did not allow tribal autonomy to persist as it has in the present area of the United States. Physical destruction of large portions of the massive native populations was more overwhelming; physical integration of those who survived was more complete. Spanish and Portuguese policy did not allow the same degree of native legal existence apart from the institutions of the dominant society.

In British America, on the other hand, the colonists treated many of the Indian groups as independent nations with whom formal treaties and agreements were made. This policy was followed despite the fact that the Crown claimed ultimate sovereignty in all lands discovered and to be discovered when it granted royal charters and letters patent to those exploring or settling in the New World. The assertion of sovereignty over the lands of the New

\footnotetext{
* Director, Office of American Studies. Smithsonian Institution.
}

1. 73 Wash. 2d 677, 687, 440 P.2d 442, 448 (1968). 
World was directed primarily at competing European states, who denied each other's pretensions to sovereignty over lands casually explored or lightly settled. Occupation rather than discovery increasingly became the only proof of sovereignty recognized by Europeans in their dealings with one another. Against the Indians the claim to European sovereignty was not pressed until much later, after Indian nations had lost their original power and could not contest the assertion of European title. ${ }^{2}$

The ambiguities inherent in the European policy were gradually clarified. In North America, the doctrine of the right of preemption was developed to stem the confusion. By this doctrine, most effectively articulated by Secretary of State Thomas Jefferson and Secretary of War Henry Knox in the 1790s, the Indian nations maintained full possession of their lands, but the United States retained the exclusive right to purchase any Indian land when the Indians chose to sell. In addition, of course, conquest of land in a just war was a valid method of acquisition. Although the concept of a just war is associated primarily with medieval theorists, in fact the doctrine, without ecclesiastical sanction or interpretation, continued to inform legislatures in British America before and after the Revolution. ${ }^{3}$

Why were Indian nations allowed to retain their separate and distinct status? First, English settlements did not result from a single ímpulse; nor were they under unified control. Charter colonies, proprietary colonies, and royal colonies, each with separate links and responsibilities to the mother country, found themselves dealing with local Indian nations of varying power and uncertain disposition. Each colony, separated from England by a vast ocean, had to determine how best to deal with the native inhabitants they encountered. Second, there was no agreement on what law applied to Englishmen who went abroad: indeed, it took a revolution to determine what rights the colonists had in the New World. Third, there was no coherent system of law spelling out the relationship that was to be established with Indians. The English had no compilation similar to the Spanish Laws of the Indies to guide them in their relations with the Indians. ${ }^{4}$ As a result, Indian nations in North America were able to deal with the English (and their

2. See generally W. Washburn, Red Man's Land/White Man's Law: A Study of the Past and Present Status of the American Indian (1971).

3. The Northwest Ordinance of 1787, for example, assured the Indians of the Old Northwest that they would "never be invaded or disturbed, unless in just and lawful wars authorized by Congress . . ." Sources and Documents Illustrating the American Revolution, 1763-1788, and the Formation of the Federal Constitution 231 (S. Morrison ed. 1951). For an informative account of the origins of the Ordinance and its predecessor Ordinance of 1784 see Berkhofer, Jefferson, the Ordinance of 1784, and the Origins of the American Territorial System, 29 WM. \& MARY Q. 231 (1972).

4. For a discussion of the Spanish law see W. Washburn, supra note 2, at 6-8. See also ThE New Laws for the Government of the Indies and for the Preservation of the Indians, 1542-1543 (1968); Washburn, Law and Authority in Colonial Virginia, in LAW AND Authority IN Colonial America: Selected Essays 116 (G. Billias ed. 1965). 
American successors) largely in terms of ad hoc problems, since the English tended to base their decisions on expediency rather than abstract theory.

Many of the Puritan divines and colonial governors sought to justify their claims to Indian lands by arguing that European farmers had a right to settle in areas that were incompletely possessed by nomadic hunters or insufficiently utilized by native agriculturalists. In such Puritan writings as John Cotton's God's Promise to his Plantation, ${ }^{5}$ this claim was grounded in divine sanction. In later years, stripped of its theological overtones, it would reappear in Theodore Roosevelt's assertion: "This great continent could not have been kept as nothing but a game preserve for squalid savages."6

Despite such theologically tinged arguments most of the colonists' dealings with the American Indian were effected through a variety of practical agreements. These agreements accepted the right of the Indian to possess the land to which he laid claim, although such lands were subject to transfer to whites by virtue of war, sale, or the disappearance or departure of the original inhabitants. Purchase was probably the principal means by which Indians transferred the land title of the present area of the United States to whites. Felix Cohen, the great authority on Indian law, noted that up to 1947 some $\$ 800$ million of federal funds had been appropriated for the purchase of Indian lands. The federal government had not always honored the principle of respect for Indian possessory rights, Cohen pointed out, but few other countries could boast a better record. ${ }^{7}$ To compensate for the many instances of the government's failure to deal honorably with the Indian, Congress, in 1946, created the Indian Claims Commission. The Commission continues to hear claims in law and equity arising under the Constitution, laws, treaties, and executive orders, as well as claims that would result if the treaties, contracts, and agreements between the claimant and the United States were revised on the ground of fraud, duress, unconscionable consideration, mutual or unilateral mistake, whether of law or fact. Indeed, the powers of the Commission extend to hearing claims based upon "fair and honorable dealings that are not recognized by any existing rule of law or equity." 8

Although direct purchase of land by English colonists was not uncommon, most of the agreements between whites and Indians took the form of a treaty. Treaties could be either oral or written, and it was with great solemnity and formality that the colonists entered into them. For example, the negotiations between Plymouth colony and the Wampanoags commenced, in the spring of 1621 when, as a Pilgrim chronicler noted, Massasoit, the Wampanoag chief, was ushered ${ }^{9}$

5. See J. Cotton, Gon's Promise to his Plantation (1630).

6. 1 T. Roosevelt, The Winning of the West 90 (1889).

7. Cohen, Original Indian Title, 32 Minn. L. Rev. 28, 45-46 (1947).

8. 60 Stat. 1049 (1946) (codified in 25 U.S.C. $\$ 70($ a) (1970)).

9. Quoted from Mourt's Relation, in W. Bradford, Of Plymouth Plantation, 1620-1647, at 
... to an house then in building, where we placed a green rug and three or four cushions. Then instantly came our Governor, [John Carver, who died shortly after] with drum and trumpet after him, and some few musketeers. After salutations, our Governor kissing his hand, the King kissed him; and so they sat down. The Governor called for some strong water and drunk to him; and he drunk a great draught, that made him sweat all the while after.

Squanto, an Indian who had learned English in England after being kidnapped by an English ship captain, served as interpreter. Carver's successor, William Bradford, later recorded the terms of the peace: ${ }^{10}$

1. That neither he nor any of his should injure or do hurt to any of their people.

2. That if any of his did hurt to any of theirs he should send the offender, that they might punish him.

3. That if anything were taken away from any of theirs, he should cause it to be restored; and they should do the like to his.

4. If any did unjustly war against him, they would aid him; if any did war against them, he should aid them.

5. He should send to his neighbours confederates to certify them of this, that they might not wrong them, but might be likewise comprised in the conditions of peace.

6. That when their men came to them, they should leave their bows and arrows behind them.

The peace concluded in the treaty of 1621 was faithfully kept throughout the lives of Massasoit and Governor Bradford. The peace began to unravel, however, after the Englishman's death in 1657 and the Indian's in 1660. Relations between the colony and Philip, the successor to Wamsutta (who had succeeded Massasoit), deteriorated as misunderstanding was piled upon insult. In 1671 the treaty relationship between the Indians and Plymouth was renegotiated, as a result of which the Wampanoags became virtual subjects or pawns of the colony. ${ }^{11}$ Our knowledge of the Indian reaction to the Pilgrim moves is clouded, but there seems no doubt that the resulting "conspiracy" and war which ravaged New England derived from a desperate feeling on the part of the Indians that the autonomy they had enjoyed in earlier years had been destroyed, and that their only hope of honorable survival lay in war. ${ }^{12}$

The treaty form of negotiating differences between Indians and whites has frequently been the object of ridicule or shame. Too often laymen and historians alike have assumed that such negotiations were either a farce or a fraud, in the course of which scheming white men imposed their terms upon simple-minded Indians. The classic example, hallowed in the annals of popular culture (whose influence on our understanding of the subject should not

80 (S. Morison ed. 1952). See also G. Langdon, Pilgrim Colony: A History of New Plymouth, 1620-1691, at 152 (1966); A. Vaughan, New England Frontier: Puritans and Indians, $1620-1675$, at $71-73(1965)$.

10. W. BradFord, supra note 9 , at 80-81.

11. G. LANGDON, supra note 9, at 160-61.

12. Washburn, Book Review, 82 Pa. Magazine Hist. \& Biog. 473-74 (1958). 
be overlooked) is the purchase of Manhattan Island by the Dutch for twentyfour dollars from the local Indians. While instances of fraud and deceit in treaty making are not lacking, it must be remembered, particularly for this formative period in American history, that the treaty process was one in which whites and Indians, bargaining from varying positions of strength and weakness, sought agreements or concessions each regarded as desirable or necessary. Often the Indians placed greater value on trade items, such as guns and beads, than on marginally used lands. ${ }^{13}$ Thus, agreements reflected different values and interests as well as differences of power. ${ }^{14}$

With the achievement of national independence the government of the United States was faced with the question of how seriously treaties with the Indians should be regarded. The Constitution granted the President the power "by and with the Advice and Consent of the Senate to make Treaties." 15 No distinction was made between treaties with Indian nations and those with foreign powers. In a communication to the Senate, dated September 17, 1789, President George Washington wrote: "It doubtless is important that all treaties and compacts, formed by the United States with other nations, whether civilized or not, should be made with caution, and executed with fidelity." 16 Washington and his early successors attempted to execute Indian treaties faithfully, although they were often frustrated by the inability of the federal government to prevent state or local action against Indian groups in violation of earlier treaties.

The fact that not all Americans agreed with George Washington is implicit in the way in which the President's communication was phrased. A steady undercurrent of disagreement with the treaty process surfaced in the nineteenth century, particularly among individuals like General Andrew Jackson, who, as an army officer and territorial governor in the years following the War of 1812, had frequently been called upon to negotiate Indian treaties. Jackson increasingly came to feel that dealing with Indians in formal treaties was "an absurdity" and an anachronism. ${ }^{17}$ It is true that as Indian power

13. Washburn, Symbol, Utility, and Aesthetics in the Indian Fur Trade, 40 MinN. Hist, no. 4, at $198-202(1966)$

14. It is noteworthy that treaty negotiations were conducted in the Indian style of address and tended to proceed at an Indian pace. This was not, I would assert, an expression of condescension on the part of the whites. It was rather the necessary pre-condition to successful negotiations with the Indians who continued in a powerful position throughout the early centuries of contact with the whites. Indeed, the whites' willingness to utilize the Indian form of negotiation rather than to insist on European forms suggests a grudging admiration for the eloquence and dignity of the Indian adversaries they faced. Benjamin Franklin was so impressed with the eloquence of the native inhabitants that he published the text of a number of the early Pennsylvania Indian treaties. See, e.g., Indian Treaties Printed by Benjamin Franklin, 1736-1762 (J. Boyd ed. 1938). See generally W. Washburn, The Indian in America 99-100 (1975).

15. U.S. CONST. art. II, § 2.

16. 1 American State Papers, Class II, Indian Affairs 58 (1832). See generally W. Washburn, The American Indian and the United States (1973).

17. R. Satz, American Indian Policy in the Jacksonian Era 10 (1975). 
declined and white power increased the consequences of breaking or ignoring earlier Indian treaties became less serious. Nevertheless treaties continued to be made in good faith until 1871, when a rider to a House of Representatives appropriation bill ended the process for the future even while acknowledging the validity of treaties made in the past. ${ }^{18}$

In the mid-nineteenth century, as white settlers rapidly moved westward, the autonomy of the western Indian nations suffered a series of blows. Implicit in the concept of the autonomy of the western Indian nations was the idea of an "Indian Barrier," fixed at the western boundary of the existing white settlements, beyond which all Indians would live free from white control. As white settlers penetrated this barrier, the federal government trailed behind, trying to provide a viable and stable relationship between the white newcomers-whether trappers, traders, miners, ranchers, missionaries, or agriculturists-and the affected Indian tribes.

The expedient seized upon by the government in the 1840s and 1850s to meet the new situation was the creation, by treaty, of a series of reservations which would serve to concentrate the various Indian nations away from the major paths of white westward movement. Isolation would also make it easier for government officials and missionaries to implement programs for "civilizing" the native populations. Once again American policy in this period was hastily improvised in response to a series of specific problems. Although framed in theoretical terms, the policy was not an expression of a coherent political or philosophical doctrine but a practical response to white pressure on the "permanent Indian barrier."1"

The destruction of many of the reservations at the end of the nineteenth century resulted from a similar expedient response to the pressure of white settlers on the reservations created in the $1840 \mathrm{~s}$. The crisis came to a head in the 1870 s with the continuing rapid expansion of white population. The new weapon in the white arsenal was the railroad, which provided a physical presence of white power in the heart of the Indian country and guaranteed rapid movement of white military power wherever needed. Indian lands, though seemingly protected by the treaties negotiated in the $1840 \mathrm{~s}$ and $1850 \mathrm{~s}$, were increasingly subject to invasion by undisciplined and unregulated frontiers-

18. The end of the treaty making process was, interestingly enough, largely the result of the insistence of Henry L. Dawes. When chairman of the Appropriations Committee of the House of Representatives, Dawes stipulated that the Senate do away with the treaty system as the price for obtaining appropriations from the House for carrying out the government's obligations to the Indians. Dawes's purpose, it has been argued, was to break up the treaty system as the first step toward general allotment of Indian lands, a goal reached in the Dawes Act of 1887, passed when Dawes was a member of the United States Senate. W. Washburn, The Assault on Indian Tribalism: The General Allotment law (Dawes ACt) of 1887, at 25 (1975), quoting from F. Nicklason, The Early Career of Henry L. Dawes, 1816-1871, at 369 (unpublished thesis at Yale University 1967).

19. See R. Trennert, Alternative to Extinction: Federal Indian Policy and the BeGinnings of the Reservation System, 1846-1851 chs. 1-4 \& epilogue (1975). 
men. Miners rushed into the Black Hills of the Sioux Reservation in search of gold. Stockmen and settlers invaded the homelands of the Utes of Wyoming and the Nez Perce of Washington and Idaho. Even the Indian Territory, inhabited by Indians who had been coerced or induced into moving west to form the prototype of a separate Indian state or territory, was under constant threat of invasion by white ruffians perched on its borders. The outcome of this pressure was occasionally war. Chief Joseph and his Nez Perce were humbled and defeated in 1877. Even the Sioux, though they destroyed George Custer's Seventh Cavalry Regiment, gained only temporary satisfaction before being crushed by larger forces. These military confrontations were the outward expressions of a crisis that seemed to men of both good and ill will to require radical solutions.

The solution proposed was to break up the reservations by dividing the communally held lands into individualized parcels. Tribal members would be given enough land to allow them to become farmers. The surplus remaining after individual allotments were made would be sold to whites, the proceeds going to assist in the educational and "civilizational" process by which Indians would be integrated into white society. The proposal received wide support, not only from those who were eager to obtain Indian lands but from white people of good will, frightened by the invasion of Indian lands, who formed Indian rights organizations and agitated for a solution to the dilemma. Viewed in the most favorable light, the "friends of the Indians" sought to save the Indians from destruction by authorizing the government to take from them some of their lands in exchange for a stronger title to the remainder. The surplus land would be sold to appease the land-hungry white settlers who, it was argued, might otherwise overrun the reservations and completely dispossess the Indians. Profits from the sale of the lands would go to support the adjustment of the Indians to their new condition in life. ${ }^{20}$

The proposal was enacted into law with the passage of the General Allotment Act of 1887, popularly known as the Dawes Act, after its champion in the Senate, Henry L. Dawes of Massachusetts. ${ }^{21}$ Historians still debate the motivations behind the Dawes Act. To some, the threat to the Indian land base and tribal integrity was not sufficient to warrant a wholesale retreat from the system by which Indian-white relations had been conducted in the past: Others argue that the friends of the Indians acted just in time to save them from being totally deprived of their remaining lands. Scholars have attempted to find evidence of selfish interests steering the legislation to enactment, but so far no one has been able to demonstrate that the act was the result of the improper influence of railroads, miners, settlers, or others who stood to profit from the results of allotment. The principal force behind the law was the vast

20. See W. WASHBURN, supra note 18.

21. Ch. $119, \S 1,24$ Stat. 288 , as amended, 25 U.S.C. $\$ 331$ (1970). 
corps of Indian rights organizations who convinced themselves that allotment and assimilation were the only solutions to the Indian "problem."

The Dawes Act was addressed not only to the issue of collective landholding but to the issues of tribal organization and the legal status of individual Indians. Increasingly during this period, the movement was toward the exercise of federal, as opposed to tribal, jurisdiction over individual Indians and toward inclusion of the Indians within the body politic as full citizens. In these issues, as in those concerning land tenure, policy and circumstance deeply influenced one another.

From the earliest period of American colonial history, individual Indians had entered into a wide range of associations with whites. For the most part these relationships were characterized by inequality and political separation. Even the Indian converts in the "Praying Towns" of seventeenth-century Massachusetts lived not as fully equal citizens within the Puritan Commonwealth but as carefully controlled associates. ${ }^{22}$ In later years, some Indians became members of white communities by virtue of the allotment provisions of early treaties, or by individual choice. However, the legal status of such individuals was rarely subject to thoughtful analysis as long as their numbers were small and the Indian nations continued to exist as separate and isolated enclaves.

But as pressures mounted for the breakup of tribal lands and whites came to live in greater proximity to western Indian settlements, some clarification of the legal status of the individual Indian became necessary. Legislation affecting the Indian's legal status was stimulated by two dramatic cases occurring in 1883 and 1884 , in the midst of the debate over the breakup of the reservations and the destruction of tribal authority. The decision in Elk $v$. Wilkins $^{23}$ played a significant role in shaping the Dawes Act, while the case of Ex Parte Crow Dog ${ }^{24}$ inspired legislation concerning criminal jurisdiction over individual Indians.

In the case of Elk $\%$. Wilkins, the plaintiff, an Indian who had voluntarily separated himself from his tribe and taken up residence among the white citizens of Omaha, Nebraska, was denied the right to register to vote by Wilkins, the local registrar, on the grounds that he was not a citizen of the United States. The decision was upheld by the Supreme Court, though two justices dissented. The decision in Elk acutely embarrassed the proponents of severalty legislation. Their argument that tribalism had to be destroyed in order to allow the individual Indian to assume his rightful place in white society seemed, in the light of the Supreme Court's decision, either false, hypocritical, or both. If the Indian were to lose his tribal affiliation and to move into white

22. See, e.g., Kawashima, Legal Origins of the Indian Reservation in Colonial Massachusetts, 13 AM. J. Legal Hist. 42 (1969); Kawashima, Jurisdiction of the Colonial Courts Over the Indians in Massachusetts, 1689-1763, 42 NEw ENGLAND Q. no. 4, at 532-55 (1969).

23. 112 U.S. 94 (1884).

24. 109 U.S. 556 (1883). 
society, he would be left in limbo. Friends of the Indian protested vigorously against the Elk decision. At the same time they encouraged Senator Dawes to write into the severalty legislation the provision that every Indian born within the territorial limits of the United States, ${ }^{25}$

... to whom allotments shall have been made under the provisions of this act, or under any law or treaty, and every Indian born within the territorial limits of the United States who has voluntarily taken up, within said limits, his residence separate and apart from any tribe of Indians therein, and has adopted the habits of civilized life, is hereby declared to be a citizen of the United States....

The Dawes Act did not fully resolve the "problem" of reconciling the Indian's status as an Indian with his status as a citizen of the United States. It took another historical event (rather than logic or theory) to stimulate Congress to clarify the status of the individual Indian. In 1924 the Congress declared citizens all Indians not already so designated. ${ }^{26}$ The remarkable role played by Indians in World War I, both on the battlefield and in the domestic war effort, made their exclusion from full participation in the political process seem arbitrary and unjust. From the white point of view, the bravery and dedication of Indians in World War 1 -whether based on the warrior values of Indian culture or other motivations-compounded the injustice of their exclusion from the country's politics, particularly at a time when America welcomed to full political equality millions of immigrants from Europe. ${ }^{27}$ Just as Elk $v$. Wilkins stimulated further consideration of the citizenship status of Indians, Ex Parte Crow Dog raised the issue of criminal jurisdiction over individual Indians.

Crow Dog had killed Spotted Tail, a fellow Sioux, within the reservation boundaries in retaliation for the latter's appropriating the wife of Crow Dog's friend. Although the Sioux had imposed their own justice, federal agents arrested Crow Dog and charged him with murder. He appealed for a writ of habeas corpus on the grounds that federal courts lacked jurisdiction over crimes committed by one Indian against another in Indian country. The Supreme Court agreed with Crow Dog's argument and set him free, noting that any prosecution must be pressed within the judicial system of the tribe. The

25. Indian General Allotment Act of 1887, ch. 119, §6, 24 Stat. 390.

26. Act of June 2, 1924, ch. 233, 43 Stat. 253 (codified in 8 U.S.C. $\$ 140(a)(2)(1970)$.

27. See W. WASHBuRs, supra note 14 , at 252 . The 1924 declaration of Indian citizenship did not, however, clarify all confusion concerning the rights and duties of Indian citizens. It did not, for example, clarify the issue of eligibility to vote in state elections. Thus, as late as the 1950s, some states, particularly in the southwest, refused to recognize Indians living on reservations as "residents" for voting purposes. See, e.g., Allen v. Merrell, 6 Utah 2d 32, 305 P.2d 490 (1956); Rothfels v. Southworth, 11 Utah 2d 169, 356 P.2d 612 (1960). The Utah statute was later repealed. The fact that reservation Indians are exempt from state and local taxes but are eligible to stand for office and vote in those areas continues to disturb neighboring whites. Navajos Who Pay No Tax Seek County Role in Arizona, N.Y. Times, Feb. 11, 1974, at 24, col. 3; Shirley v. Superior Court, 109 Ariz. 510,513 P.2d 939 (1973). 
response of Congress, outraged at the latitude thus conceded to the tribes, was to pass the Major Crimes Act of 1885, which extended federal criminal jurisdiction to the seven major crimes of murder, manslaughter, rape, assault with intent to kill, arson, burglary, and larceny. ${ }^{28}$

Congress did not, however, move to assert full jurisdiction over all reservation activities. Owing, in part, to successful experiments by local agents with tribal police and tribal judges, bureaucrats and legislators gave support to tribal institutions which contributed to the reduction in Indian-white tensions. Because there was no comprehensive theory of federal-Indian relations guiding policy in every domain of Indian life, indigenous institutions were able to survive even in the face of the dominant, if loosely articulated, program of individualized allotment and status contained in the Dawes Act. ${ }^{29}$

The General Allotment Act of 1887 reflected the rampant individualism and economic laissez-faire philosophy of America at the end of the nineteenth century. Whatever the effects of that philosophy in other areas of American economic life its particular form of application to the Indians proved totally unsuccessful. Already by the 1920 s it was clear that Indians were not developing into prototypical American farmers: the inadequate size and quality of allotments, the poor facilities for health and education, and the positive attachment of Indians to their tribal identities contributed to this situation. When Lewis Merriam's famous report to the Secretary of the Interior was published in 1928, recognition of the failure of American Indian policy was required. Just as the philosophy of laissez-faire economics influenced the formulation of the Dawes Act, so too the next major piece of legislation, the Indian Reorganization Act of 1934, was influenced by the reconsideration of the ethic during the Great Depression.

For many Americans during the years of the Depression collectivism, whether of the Soviet variety or of the traditional native American variety, suddenly had new appeal. John Collier, who was selected as Commissioner of Indian Affairs by President Franklin D. Roosevelt and Secretary of the Interior Harold Ickes, had been deeply influenced in his earlier years by the communal values he had observed in Indian societies of the southwest. In devising a new policy for the Indian as part of the general restructuring of American society in the period of the New Deal, Collier sought to reestablish these values throughout the Indian segment of American society. ${ }^{30}$

28. 23 Stat. 385, The Major Crimes Act has been amended on numerous occasions since. The present version covers thirteen crimes, 18 U.S.C. $\$ 1153$ (1970). There is, however, some question whether the act confers exclusive or concurrent jurisdiction on the federal courts. $C f$. 1 INDian L. ReP. no. 3, at 52 (1974). The Criminal Justice Reform Act, S. 1, 94th Cong., 1st Sess. $\$ 203$ (1975), would also affect the existing jurisdictional scheme. $C f$. 2 INDIAN L. REP. no. 5 , at 30 (1975).

29. See, e.g., W. Hagan, Indian Police and Judges: Experiments in Acculturation and Control 34-43 (1966).

30. Collier even believed that the communal values of the Indians could help shape a similar orientation of white society. See Failure to Create a Red Atlantis: John Collier and the Con- 
Collier's dream of a "red Atlantis"-as one scholar has termed it-came near to realization. ${ }^{31}$ But the program ran up against the very individualism which Collier's predecessors had successfully fostered in many American Indian tribes. Collier's attempt to ban the inheritance of lands already allotted to individual Indians (coupled with his proposed ban on further allotments and the return to communal ownership of all surplus Indian lands) was met by bitter opposition in areas like Oklahoma, where many Indians thought more of their newly gained individual property than of tribal integrity. The aim of the nineteenth-century reformers-to encourage individualistic values -had, Collier recognized to his sorrow, been partially realized. The new cultural climate in many Indian communities caused Collier to modify his plan to return individual land holdings to communal ownership. Instead he made particular efforts to maintain as fully communal societies those tribes the aridity of whose lands had made application of the acreage provisions of the General Allotment Act patently impractical. Collier also sought authorization for the purchase on the open market of individual land holdings that could then be returned to tribal control. ${ }^{32}$

As part of his scheme for strengthening Indian communal societies, Collier encouraged the revitalization of tribal governments, hitherto the object of direct assault by all government policies. The Indian Reorganization Act gave legal recognition to tribal governments as distinct from federal, state, and local governments. At the same time the Act maintained and strengthened prior recognition of the trust responsibilities of the federal government to the Indians. In order to win approval for the new structure in a white dominated legislature, Collier prescribed certain organizational procedures and forms intended to reassure Congress that responsible democratic government-as white Americans defined it-would be established. Thus tribal leaders were to be elected by ballot, each adult Indian man and woman having an equal vote. Traditional methods of selection by consensus, heredity, or appointment by a smaller element of the tribe were ignored or prohibited. Moreover, each tribe was to draw up a constitution and a set of by-laws for the organization and operation of tribal affairs. Not insignificantly, the Secretary of the Interior was made the reviewing officer for many of the processes by which tribal governments would function.

The provisions of the Indian Reorganization Act have been the source of sharp conflicts within many reservation groups. For example, spokesmen for the American Indian Movement at Pine Ridge in 1972 demanded the ouster of the elected tribal government, the discontinuance of electoral procedures

troversy Over the Wheeler-Howard Bill of 1934, address by Kenneth R. Philp, National Archives Conference on Research in the History of Indian-White Relations, Washington, D.C., June 16, 1972. See also W. WASHBURN, supra note 14, at 254-57.

31. Philp, supra note 30.

32. Id. 
authorized under the Act, and the return to "traditional" forms of leadership selection. Other segments of the tribe argued that a one man/one vote system was a more equitable method of determining leadership. The Indian Reorganization Act may or may not have contributed to internal tribal factionalism by stressing proportion of Indian parentage for tribal membership or highlighting degrees of assimilation to white values. But what is certain is that the Act has, during a crucial period in American Indian history, preserved and strengthened the concept of tribal authority. "As a reform measure," writes Vine Deloria, Jr., "Collier's original draft of the Indian Reorganization Act was so thoughtful, philosophical, and ahead of its time that it had a hard time gaining credibility." 33 Indeed, says Deloria, "Collier had more faith in Indians than they had in themselves." 34 He concludes: "The present contention of Indian activists and others that the Indian Reorganization Act was a step away from the traditional right of Indians to govern themselves is inaccurate if they mean that the scope of legal powers was reduced by the adoption of the act." 35

The Indian Reorganization Act remains the guiding expression of federal Indian policy. Although Congress acted in 1953 to terminate federal services and jurisdiction over Indians as rapidly as possible, the economic hardship accompanying that policy has led to its subsequent rejection. ${ }^{36}$ And the Indian Civil Rights Act of $1968,{ }^{37}$ which extended most of the constitutional requirements of the Bill of Rights to reservation groups, has raised difficult issues of the relations between organized tribal governments and their individual members. Throughout, the Supreme Court has reaffirmed the concept of tribal authority, even though its precise boundaries and implications have been the subject of extensive litigation. ${ }^{38}$

American Indian policy has, therefore, been an amalgam of insight and greed, implicit bias and practical concern. At its best, it has developed in response to mutual understanding rather than blind adherence to abstract doctrine. Internal disputes will continue within Indian communities, but the fact that the Indian tribe has survived as a viable legal entity in our day is a tribute to the good will and dedication of men like Governor William Bradford of Plymouth Colony in the seventeenth century and John Collier in the twen-

\footnotetext{
33. V. Deloria, Jr., Behind the Trail of Broken Treaties 196 (1974).

34. Id. at 199 .

35. Id. at 204 .

36. H.R. Con. Res. 108, 67 Stat. B 132 (1953). This led to termination statutes such as 25 U.S.C. $\$ \S 891-902$ (1954). The Menominee Restoration Act, 25 U.S.C. $\$ 903$ (Supp. I1I, 1974) has since repealed this termination statute. See generally Orfield, $A$ Study of the Termination Policy, in 4 Subcomm. on Indian Education, The Education of American indians, The Organization Question 673 (1970). See also Freedom With Reservation: The Menominee Struggle to Save Their land and People (D. Shames ed. 1972).

37. 25 U.S.C. $\$ \S 132-03$ (1970).

38. See, e.g., McClanahan v. Arizona State Tax Commin, 411 U.S. 164 (1973).
} 
tieth; and to the practical, non-theoretical ideology of the English settlers and officials who established the American nation. The legal relations of the United States with the American Indians reinforces Justice Oliver Wendell Holmes's dictum that "[t]he life of law has not been logic: it has been experience." 39

39. O.W. Holmes, The Common Law 5 (M. Howe ed. 1963). 